\title{
The possibilities of criterion-oriented testing in verifying the achievements of teachers
}

\author{
Aleksandra Yurievna Sergienko ${ }^{1 *}$, Irina Ivanovna Sokolova $^{2}$, and Olga Sergeevna Spirina ${ }^{3}$ \\ ${ }^{1}$ Branch of Federal State Budgetary Scientific Institution "Institute of Management of Education of \\ Russian Academy of Education" in St. Petersburg, Cherniakhovskogo str., 2, St. Petersburg \\ ${ }^{2}$ The department of humanitarian and socioeconomic disciplines, Federal State Military Educational \\ Institution of Higher Education «Military Telecommunications Academy named after the Soviet \\ Union Marshal Budenny S.M." of the Ministry of Defense of the Russian Federation, Tikhoretskiy \\ pr., 3, St. Petersburg, Russia \\ ${ }^{3}$ Federal State Military Educational Institution of Higher Education «Military Telecommunications \\ Academy named after the Soviet Union Marshal Budenny S.M." of the Ministry of Defense of the \\ Russian Federation, Tikhoretskiy pr., 3, St. Petersburg, Russia
}

\begin{abstract}
The article presents the results of empirical research on perception of teachers from military engineering university about the features of didactic testing and on methodologies of diagnostics used by experienced and young teachers. It also presents the results of the survey on students' learning motivation according to the achievement goal theory. Students have been identified as being oriented towards mastery goal, and concentrate on getting new knowledge and skills that lead to professional and personal growth. It has been proved possible to develop methods for determining the effectiveness of pedagogical action and communicative interaction between the teacher and the student using didactical criterionoriented testing. One of the goals is to assess teacher's performance as a factor influencing students' cognitive activity, their results and motivation. The method of formalization by mathematical means of the modeling process and representation of criterion-oriented testing results as a communicative task of interaction between the teacher and the student is described. Prospects for use of theoretical bases, ideas and methods of educational evaluation in criterion-oriented testing and in verifying teachers' achievements are discussed.
\end{abstract}

\section{Introduction}

Testing represents a form of pedagogical diagnostics as a method of obtaining information about the educational process effectiveness. In line with the competency-based paradigm the student is regarded as motivated active participant of the educational process. His/her activity becomes dominant and determines the possibility to learn, upgrade and use knowledge independently and consciously. Teacher's work does not lose its managerial character. Teacher should create certain conditions in class and organize students' work so

\footnotetext{
* Corresponding author: sashsky@yandex.ru
} 
that they help to unleash the potential of the learner and increase awareness of knowledge and skills for further professional and personal development. Learners' success as research and educational practice show are largely determined be their motivation and teacher's skills. Adequate (correct) targets and methods of diagnostics, its criteria under certain conditions can not only help assess the performance of learners, but also verify teacher's achievements.

Russian researchers correctly point out that on the basis of test results, it is possible to compare the quality of different textbooks and methodological systems. In this context the problem of diagnostics in higher education becomes relevant as it becomes voluminous and multifaceted. The educator's performance and impact on learners should also be assessed, because it contains many important tasks such as: ability to plan and design a lesson, analyze their own activities, implement different innovative technologies and monitor their effectiveness, motivate students, organize and stimulate their cognitive activity, etc. However, there is currently a lack of methods and criteria of diagnostics of teachers' performance results. The criterion-oriented testing may be used for these purposes.

\section{Materials, methods, results}

Testing as a modern diagnostic method relies on scientifically sound statistical patterns in examining large number of inspections of educational results. It ensures the technological soundness of diagnostic procedures, allows storage and comparison of the results. Systematic objective monitoring provides information on the evolution of students' education quality in case of making changes to educational system. It makes possible comparing the quality of education in different countries on the basis of the same criteria. However, criteria-oriented testing is recommended in ongoing didactic testing.

Three main methods were used in the study: analysis of data from researchers on the reported problem, teacher survey, and mathematical simulation of student testing.

The sample survey of teachers from humanitarian departments of the Military Telecommunications Academy (78 respondents) showed that they devote no more than 10 $20 \%$ of teaching time to pedagogical diagnostics (Fig. 1). Teachers are not sufficiently aware of the proper diagnostic instruments to use in accordance with objectives of diagnosing educational outcomes, and are not fully familiar with the concept of pedagogical diagnostics. They generally identify pedagogical diagnostics with didactic control, which mostly focuses on the identification of student knowledge, skills and competencies acquired in the educational process. The individual and personal qualities of students are hardly taken into account. 


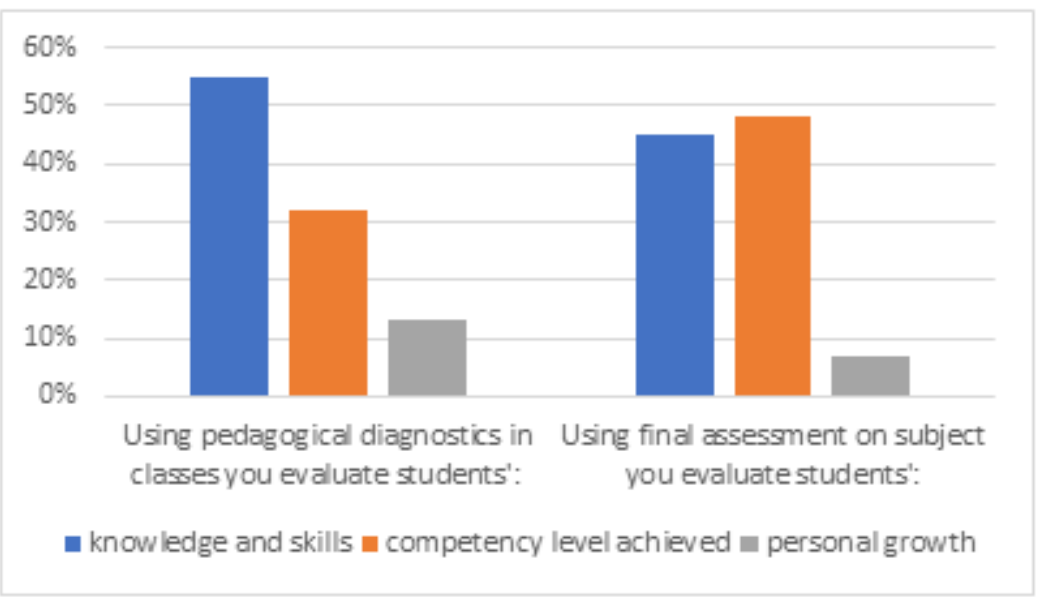

Fig. 1. Subject of ongoing and final diagnostics from the point of view of teachers.

Testing as a method of pedagogical diagnostics is not fully explored. There is a lack of systematic knowledge in the field of testing, including knowledge on use of testing to correct teaching under ongoing pedagogical control. The problem that researchers noted in the eighties of the last century remains relevant today - it is widely believed that tests only measure the outcomes of students, but can't help identifying gaps, and moreover gaps in training [1].

The problem of underestimation of the didactic possibilities of testing, in particular by young teachers, is essential in military education. Thus, according to our research results in the Military Telecommunications Academy, only 0,04\% of adjuncts (beginning teachers) consider testing the most effective method of pedagogical diagnostics (Fig. 2). Both experienced and young teachers use oral and written interviews as traditional ways to assess educational results (Fig. 3). Despite the significant popularity of using tests as an objective measure of educational results testing does not prevail among methods of diagnostics reported by teachers, however experienced teachers use testing more often than young teachers, alternating with traditional surveys.

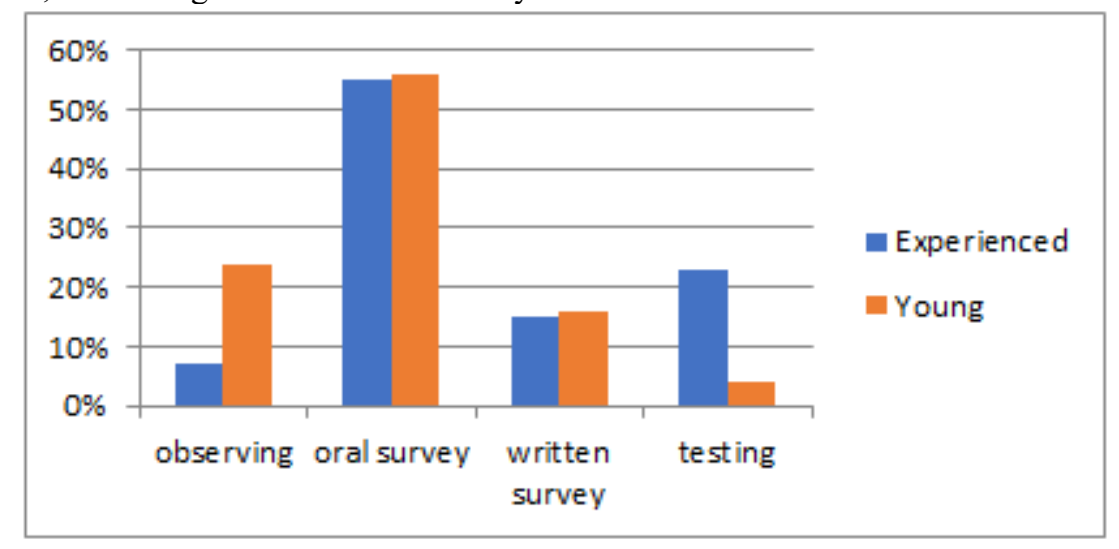

Fig. 2. Most effective method of pedagogical diagnostics. 


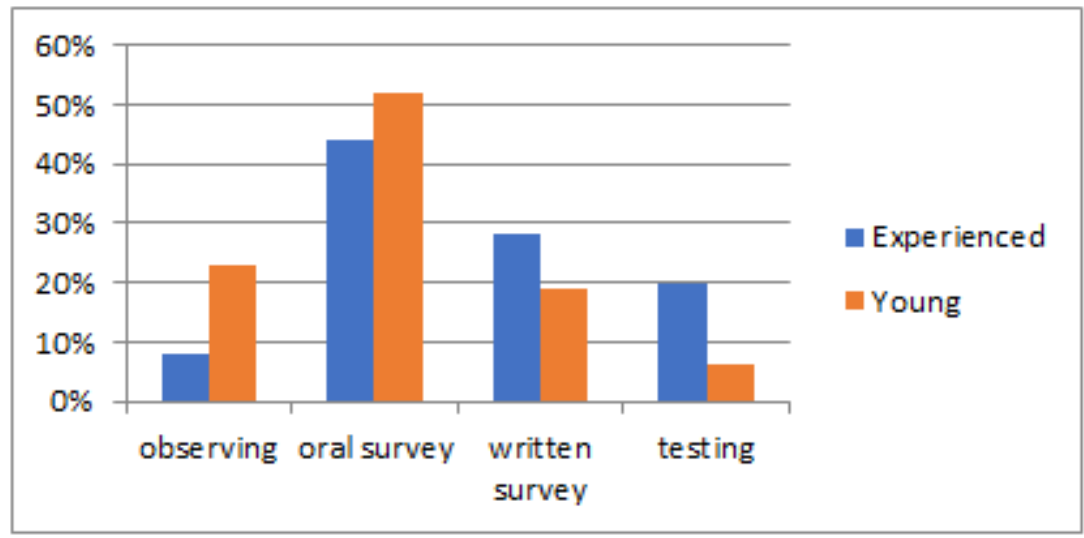

Fig. 3. Most commonly used method of pedagogical diagnostics.

In Russian pedagogy pedagogic diagnostics appears as an independent theoretical and applied field. It examines the rules of the diagnostic procedure, principles, methods and forms of diagnostics [2]. Pedagogic control is considered an integral part of pedagogic diagnostics - a system of scientifically based verification and evaluation of the results of education, training and personal development. There are instrumental and subjective methods of pedagogical control distinguished. Instrumental methods include testing (to assess knowledge) and instrumental observation (to assess actions). Subjective methods include oral survey, validation interview, written paper, pass/fail exam, control observation, etc. Four main functions of pedagogical control are identified: diagnostic, educative, organizing and disciplinary [3].

Diagnostic function involves regular analysis of learning outcomes to obtain objective and reliable information on the education process, results of learning activities and trends both positive and negative. This makes it possible to make the necessary adjustments to the teaching process itself as well as the monitoring and evaluation of learners' knowledge. Educative function is not only about acquiring knowledge, skills and competencies but also about their maintenance. It usually takes place in the course of repetition, refinement and synthesis of the content studied. This function, which is one of the most important, contributes to deepening, broadening and sustaining knowledge, skills and competencies, and also promotes interdisciplinary linkages. Organizing function is carried out by orienting learning towards a specific goal. This function is oriented to creating positive motivations in the learning process, creative atmosphere of competition and favorable conditions for cognitive expression. It is also aimed at stimulating the initiative of learners. The central organizing point of this function is the teacher's commitment to the development and use of content, forms, methods, techniques and tools to use for the goal. Disciplinary function is aimed at disciplining and educating students, and training them in systematic work. It is oriented to the development, in the process of pedagogical control, of the moral responsibility for the results of their own learning and the perseverance in achieving excellence. It also addresses building of professional qualities and the desire for continuous learning.

The review of the works of Russian educators devoted to the functions of pedagogical diagnostics is presented in the Table 1 . 
Table 1. The functions of pedagogical diagnostics and control in the works of Russian educators.

\begin{tabular}{|c|c|c|c|c|}
\hline № & Authors & Research theme & $\begin{array}{c}\text { Year of } \\
\text { publishing }\end{array}$ & Functions \\
\hline \multicolumn{5}{|c|}{ Functions of pedagogical diagnostics } \\
\hline 1. & $\begin{array}{l}\text { Borytko } \\
\text { N.M. }\end{array}$ & $\begin{array}{l}\text { The teacher's diagnostic } \\
\text { work [4] }\end{array}$ & 2006 & $\begin{array}{l}\text { Information, predictive, } \\
\text { control and corrective, } \\
\text { evaluative, promotional }\end{array}$ \\
\hline 2. & $\begin{array}{l}\text { Efremov } \\
\text { O.Yu. }\end{array}$ & $\begin{array}{l}\text { Theory and practice of } \\
\text { pedagogical diagnostics at } \\
\text { the Russian higher military } \\
\text { school [5] }\end{array}$ & 2001 & $\begin{array}{c}\text { Control and evaluative } \\
\text { (diagnostic), evolutive, } \\
\text { information, formative, } \\
\text { predictive, feedback function, } \\
\text { et al. }\end{array}$ \\
\hline 3. & $\begin{array}{l}\text { Abdulaeva } \\
\text { R.A. }\end{array}$ & $\begin{array}{c}\text { Pedagogical control in } \\
\text { secondary vocational } \\
\text { education system: } \\
\text { functions, forms, types. [6] }\end{array}$ & 2018 & $\begin{array}{l}\text { Diagnostic, educative, } \\
\text { organizing, disciplinary }\end{array}$ \\
\hline 4. & Dairi N.G. & $\begin{array}{c}\text { Content and the logic of its } \\
\text { study [7] }\end{array}$ & 1987 & $\begin{array}{c}\text { Control, evaluative, } \\
\text { educative, evolutive, } \\
\text { disciplinary }\end{array}$ \\
\hline 5. & $\begin{array}{l}\text { Izotova } \\
\text { N.V. }\end{array}$ & $\begin{array}{l}\text { Remedial control as a factor } \\
\text { for improving the quality of } \\
\text { teaching (on humanitarian } \\
\text { cycle materials) [3] }\end{array}$ & 2004 & $\begin{array}{c}\text { Diagnostic, educative, } \\
\text { organizational, disciplinary }\end{array}$ \\
\hline 6. & $\begin{array}{l}\text { Krivoshapo } \\
\text { va R.F., } \\
\text { Silutina } \\
\text { O.F. } \\
\end{array}$ & $\begin{array}{l}\text { Testing and evaluation } \\
\text { functions in training [8] }\end{array}$ & 1980 & $\begin{array}{l}\text { Orientation, diagnostic, } \\
\text { educative, disciplinary, } \\
\text { evolutive, control, } \\
\text { administrative } \\
\end{array}$ \\
\hline 7. & $\begin{array}{l}\text { Maksimov } \\
\text { V.G. }\end{array}$ & $\begin{array}{c}\text { Pedagogical diagnostics at } \\
\text { school [9] }\end{array}$ & 2002 & $\begin{array}{l}\text { Diagnostic, educative, } \\
\text { organizing, disciplinary }\end{array}$ \\
\hline 8. & $\begin{array}{l}\text { Sorokopud } \\
\text { Yu.V. }\end{array}$ & $\begin{array}{c}\text { Higher school pedagogics } \\
{[10]}\end{array}$ & 2011 & $\begin{array}{c}\text { Diagnostic, educative } \\
\text { (administrative) }<\text { evolutive, } \\
\text { disciplinary }\end{array}$ \\
\hline 9. & $\begin{array}{l}\text { Talyzina } \\
\text { N.F. }\end{array}$ & $\begin{array}{c}\text { Pedagogical psychology } \\
{[11]}\end{array}$ & 1998 & $\begin{array}{l}\text { Diagnostic, control and } \\
\text { evaluative, feedback, } \\
\text { organizing, disciplinary }\end{array}$ \\
\hline
\end{tabular}

Research on quality measurement in education [12] shows that even a slight increase in the motivation of learners influence the quality of educational process more than introduction of innovative learning technologies. Traditionally external motivation and internal motivation have been singled out in Russian pedagogy [13]. In modern studies two main theoretical approaches prevail where motivation is associated with different types of objectives. In the achievement goal orientation theory, there are two basic goals: mastery goal and performance goal [14]. Students who focus on the mastery goal concentrate on knowledge and skills that lead to personal and professional growth. Performance oriented students seek to demonstrate their skills and knowledge [15], obtain from others desired assessment of their competencies or avoid negative evaluations [16]. Result orientation is usually associated with superficial attitudes to learning and is considered to have an adverse effect on the emotional, cognitive and behavioral components of learning [17]. Mastery goal orientation is seen as stimulating learning activities and positive emotions towards them. All things been equal, this type of orientation has a positive effect on student achievements as expressed in the test results. And it is this kind of value orientation that the most successful teachers stimulate in their students.

N.G. Maloshonok et al. [18] indicate that their studies of Russian students reveal the existence of all these types of goal orientations and suggest to share in mastery goal 
orientation the goals of professional and personal development, as they directly influence the student's learning strategy. From our sample survey of second and third-year students from Military Telecommunications Academy (100 respondents, 2020) it can be seen that the predominant purpose of their higher education is to acquire professional skills ( $88 \%)$. Result orientation (getting a high rating, or a high-ranking position in the rating system) is characteristic of only $10 \%$ of respondents. Thus, the training motivation of students is mainly related to their interest in and aspiration to the future profession.

Selection of the theoretical framework to verify students' achievements using criterionoriented testing depends on which aspects of motivation it is most important to study. The choice of empirical methods of motivational research is also broad [19, 20] and can be recommended in verifying the achievements of teachers.

To what extent and by what means all functions in ongoing control are implemented depends on teacher's personal qualities, activities, motivation and possession of appropriate methodologies. Generally, all the factors that affect the educational outcomes of students might be diagnosed. And criterion-oriented tests with a clear focus on objectives and criteria should be selected as a tool.

Criteria-oriented testing requirements are justified in the works of Pechnikov A.N., etc. $[21,22]$. These are the requirements of reliability, diagnosticity, efficiency, formalizability, and multicriteriality. The reliability requirement includes the independence of the procedure from the examiner's opinion; using the scale with the resolution which corresponds to the resolution of the form of the test to present the results; the consistency of the procedure for evaluating test results for all subjects; interval estimation requirement [21]. The multicriteriality defines that control results should reflect all factors influencing the achievement of such results. It gives the possibility of test results evaluation (correctness and time of test tasks) and other subject's parameters that affect the test result.

To illustrate the application of the mathematical tools of modeling and interpreting the results of criterion-oriented testing of students, let us cite the following. The research report [23] by one of the authors (with co-authors) shows that in ongoing pedagogical control the following assumptions can be made: 1) the complexity ${ }^{I_{j}}$ of each test task is determined by reference (normative) complexity $I_{j}^{y \grave{y}}$ of a tested educational element, i.e. $I_{j}=I_{j}^{\text {yò }} ; 2$ ) each of the educational elements was presented to the learners in the test with the same instruction; 3) the learning and motivation of all learners in the process of study of all educational elements remained the same.

Then the result of any test performed according to accepted assumptions can be presented as:

$$
K_{i j}^{\hat{\imath} a \hat{}}=K_{i}^{O ́ ̈} K_{j}^{\hat{I} \hat{A}}
$$

The search of sets $\left\{K_{j}^{\hat{I} \hat{A}}\right\}$ and $\left\{K_{i}^{O \ddot{A}}\right\}$ of unknown values of learning effectiveness coefficients of the teacher and the students is proposed to represent by solving the problem on nonlinear programming of the form

$$
\left.\begin{array}{r}
\sum_{j=1}^{j=m} \sum_{i=1}^{i=n}\left(a_{i j}-K_{i}^{O \ddot{A}} K_{j}^{\hat{I} \hat{A}}\right)^{2} \rightarrow \min , \\
K_{i}^{O \mathscr{A}} K_{j}^{\hat{I} \hat{A}} \in[0,1] ; i=\overline{1, n} ; j=\overline{1, m}
\end{array}\right\}
$$


where the values of the coefficients $K_{j}^{\hat{1} \hat{A}}$ and $K_{i}^{O ́ A}$ are determined by minimizing the sum of the squares of deviations of the calculated performance indicators $K_{i j}^{i \hat{a}}=K_{i}^{O \mathscr{O}^{\ddot{A}}} K_{j}^{\hat{\hat{l}} \hat{A}}$ from their empirical values $a_{i j}$, experimentally found in the testing.

As a result of criterion-oriented test data processing using conventional method the teacher gets information about the only characteristic that is useful for achieving the goals of ongoing pedagogical control. The characteristic represents the estimations $p\left(s_{i}\right)$ of the level of learning that learners have achieved as a result of the educational process being analyzed.

Finally solving the nonlinear programming problem in addition to this unique characteristic the teacher receives: 1) estimations of the effectiveness $K_{j}^{\hat{I} \hat{A}}$ of all learning impacts which have been implemented for the education elements being tested; 2) estimations of the effectiveness $K_{i}^{O A ̈}$ of leaning activity during the period of study of the educational elements included in the test carried out by the learners. This additional information significantly improves the adequacy of communicative problem of interaction between teacher and learner in the learning process, for which the test was conducted.

\section{Discussion}

M.V. Guskova draws attention to the fact that educational results evaluation is oriented to the competencies with meta-latent nature and delayed nature of display. Another thing is that the process of competency building is influenced by contextual factors and students' learning activity development background and learning motivation. Therefore, modern ideas and methods of evaluation should be used in diagnostics [24].

Evaluation is an area of assessment, collection and analysis of information, and, at the same time, of management decision-making apparatus and external monitoring [25]. A hierarchy of factors can be identified in educational evaluation (updating the content of education, adopting innovative organizational and technological pedagogical decisions, introduction of new teaching methods, changing the style of interaction with students, improving the quality of the monitoring system in educational institutions, strengthening the involvement of students, etc.). Independent variables and predictor variables are identified for the study of subjects of educational evaluations (for which groups of evaluation subjects differ). For example, if one needs to figure out the effects of competencies on follow-up activities of graduates of educational institutions, it is possible to consider the requirements of Federal State Educational Standards in different areas as predictors, etc. Dependent or criterion variables are those that can measure the differences between groups of subjects achieved during the training program. In education, learning achievements and other educational results serve as criterion variables. To solve the problems identified in our study, indirect causation can be used in evaluation. For example, if the quality of the measures influences student motivation to acquire the competencies, the proxy variable will be the magnitude of the measurement error, because subjective estimates obtained with great measurement error reduce student learning motivation.

Thus, integrating the idea and methodology of evaluation into the system of diagnostic brings the true meaning to the diagnostics itself as a procedure that helps to identify the causes of test failures and errors, and to effectively implement training functions based on diagnostic results.

Note that national standardized tests as well as exams, portfolios, interviews, debates, discussions, professional work experience, descriptive methods, simulations, and 
observations can be used in verification of informal and nonformal education results in the teacher qualification system and validation of teachers' professional experience. The experience and communication skills of an examiner play a crucial role in this case to ensure validity, reliability and fairness of the process [26]. Verification of learning outcomes is the scope of criterion-oriented testing application. Non-trivial task of development of the system of verification teachers' professional achievements, especially the results of their informal and nonformal education, is now been addressed in modelling regional systems of teacher professional development in Russia [27]

Question of creating the conditions for the conduct of such a procedure for teachers may need to be addressed in the development of knowledge and competency verification for any professional area. In such testing, it is important to determine: whether the assessment tools are adaptable to personal features of a teacher; to which extent the assessment tools are robust and sound; what set of criteria/standards are used and how accurate they make possible to record an individual set of acquired experience; to which extent the evaluation procedures, tools and standards are clearly defined and explained to teachers, employers and educational institutions [28].

\section{Conclusion}

As can be seen from the above, pedagogical diagnostics as a knowledge-based technology should be based on a number of principles serving as its starting point and at the same time as the conditions for its organic incorporation into the holistic pedagogical process: consistency and specificity; scientific soundness of diagnostic theory and methodology; combination of diagnostic detection and correction functions; consistency and continuity of the diagnostic system; accessibility of diagnostic procedures to teachers and students; optimization of diagnostic forms and methods; comprehensiveness and predictiveness of diagnostics.

Motivation has a strong influence on learning outcomes, including those remote, important for professional development, determines the choice of educational strategies by students. On the other hand, it is teachers who have a significant influence on motivation. Through special studies, it is possible to identify, for didactic and educational purposes, the influence of the teacher in charging the motivation of the course, and thus take into account the impact of a particular type of motivation on diagnostic result. And back again, studying test strategy or using special tests, investigate student motivation and then its impact on academic success. On the other hand, knowledge of factors influencing criterion-oriented testing results, allows to refine mathematical models of its design and evaluation results. Provisions developed in the study on usability and features of criterion-oriented testing and the findings can be used to verify pedagogical achievements and in similar further studies.

\section{References}

1. N.F. Talyzina Theoretical bases of control in teaching. Moscow: Znanie (1983)

2. O.V. Almazova Psychological and pedagogical diagnostics: training manual. Ekaterinburg: Kalinina G.P., P. 22 (2007)

3. N.V. Izotova Remedial control as a factor for improving the quality of teaching (on humanitarian cycle materials). Thesis for Candidate of Educational Sciences, Bryansk. (2004)

4. R.A. Abdulaeva Pedagogical control in secondary vocational education system: functions, forms, types. Current issues in vocational training, Volgograd, no 3, pp. 2326 (2018) 
5. N.M. Borytko The teacher's diagnostic work: training manual for university students. Edited by V.A. Slastenin. Moscow, The publishing center "Academy” (2006).

6. N.G. Dairi Content and the logic of its study. Soviet pedagogy, no 9, pp. 41-45 (1987).

7. O.Yu. Efremov Theory and practice of pedagogical diagnostics at the Russian higher military school: autoabstract thesis for a Doctor of Education. St-Petersburg (2001).

8. R.F. Krivoshapova, O.F. Silutina Testing and evaluation functions in training. Soviet pedagogy, no 11, pp. 60-65 (1980).

9. V.G. Maksimov Pedagogical diagnostics at school: training manual for university students. Moscow, The publishing center "Academy" (2002).

10. Yu.V. Sorokopud Higher school pedagogics. Rostov-on-Don, Fenix (2011).

11. N.F. Talyzina Pedagogical psychology: training manual for students from pedagogical colleges. Moscow, The publishing center "Academy" (1998).

12. I.G. Lurie, A.N. Pechnikov Management of the quality of the educational process through the analysis of educational potential of its characteristics. Vestnik RGGU: Economics, management and law, 12, P. 38-57 (2007).

13. T.O. Gordeeva, O.A. Sychev, E.N. Osin Internal and external motivation of students: their sources and impact on psychological well-being. Voprosy psikhologii, 1, P. 1-11 (2013).

14. C. Ames, J. Archer Achievement Goals in the Classroom: Student's Learning Strategies and Motivation Process. Journal of Educational Psychology, vol. 80, no 3, pp. 260-267 (1988).

15. A. Kaplan, M.L. Maehr The Contributions and Prospects of Goal Orientation Theory. Educational Psychology Review, vol. 19, no 2, pp. 141-184. (2007)

16. C. Dweck Motivational Processes Affecting Learning. American Psychologist,vol. 41, no 10, pp. 1040-1048. (1986)

17. C. Ames Classrooms: Goals, Structures, and Student Motivation. Journal of Educational Psychology, vol. 84, no 3, pp. 261-271. (1992)

18. N.G. Maloshonok, T.V. Semenova, E.A. Terentiev Academic motivation of students of Russian higher education: opportunities for theoretical reflection. Voprosy obrazovania, 3, pp. 92-121 (2015)

19. O.V. Vishtak Motivation preferences of applicants and students. Social studies, 2, pp. 135-138 (2003).

20. T.O. Gordeeva, E.N. Osin Achievement and learning motivations of students with different types of academic performance, Psychological investigations: electronic scientific journal, volume 5, 24 (2012) http://psystudy.ru

21. A.N. Pechnikov, A.N. Shikov Design and application of computer-based learning technologies. St-Petersburg: BBM (2014)

22. A.N. Pechnikov, Yu.A. Vetrov Design and application of computer-based learning technologies. Book 1. St-Petersburg: BGTU (2003).

23. A.N. Pechnikov, V.A. Mitrakhovich, A.N. Savischenko et al. Report on scientific research "Study of the methodology for benchmarking the results of testing the knowledge of students in military higher education", St-Petersburg: Military Telecommunications Academy (2016).

24. M.V. Guskova Evaluation in education. INFRA-M (2014).

25. E.G. Guba, Y.S. Lincoln Effective evaluations. San Francisco: Jossey-Bass. (1981) 
26. Terminology of education and training policy: a multilingual glossary. Luxembourg: Publications Office of the European Union, 2014. URL:

https://www.cedefop.europa.eu/files/4117_en.pdf

27. A.Yu. Sergienko Verification of the results of nonformal and informal education: trends of development in Europe. Continuing education of teachers: achievements, challenges, prospects. 5 November, 2020, Minsk, Belarus.

28. European Guidelines for validating non-formal and informal learning. Cedefop, Luxembourg: Publications Office of the European Union, 2015 URL:

https://www.cedefop.europa.eu/files/3073_en.pdf. 